\title{
Effect of Different Salinity Concentrations on the Chemical analysis and Time Appearance of Feces for Cyprinus Carpio
}

\author{
Hasan Ali Al Hilali \\ Directorate of Animal Recourse, Ministry of Agriculture, Baghdad, Iraq. \\ E-mail: Hassanalhilaly89@gmail.com \\ Mohammed Shaker Al-Khshali (Corresponding Author) \\ Department of Animal Production, University of Baghdad, Baghdad, Iraq. \\ E-mail: alshaker64@yahoo.com
}

Received: March 24, 2019 Accepted: April 21, 2019 Published: April 22, 2019

doi:10.5296/ast.v7i2.14539 URL: https://doi.org/10.5296/ast.v7i2.14539

\begin{abstract}
The present study was conducted to investigate the effect of high salinity on some stress parameters of common carp (Cyprinus carpio), which gradually exposed to salt concentrations of 5,10 and $15 \mathrm{~g} /$ liter, as well as tap water (water without chlorine) (control $0.1 \mathrm{~g} / \mathrm{liter}$ ) for 90 days. Eighty fish were randomly distributed on eight glass tanks with 2 replicates, 10 fish / replicate at average weight of $15 \pm 3 \mathrm{~g}$, to study the effect of salinity on the time appearance of feces and, the chemical analysis of the body composition. The results showed that the appearance time of feces was decreased with the rise of salt concentrations of common carp. As the passage of food through digestive tract took less time in high salinities. and the appearance of feces was after 4.16 hours of feed intake in a salt concentration of $15 \mathrm{~g} /$ liter, whereas it started after 5.22 hours in a saline concentration of $10 \mathrm{~g} / \mathrm{l}$ and after 6.11 in a salt concentration of $5 \mathrm{~g} / \mathrm{l}$ in comparison with the control treatment (6.17 hours). Regarding the chemical analysis of the body composition, it was found that the moisture dropped with the rise of salinity, as it mounted to 77.09, 74.94 and $73.80 \%$ in the salt concentrations 5,10 and $15 \mathrm{~g} / \mathrm{l}$ respectively, in comparison with the control treatment $(78.45 \%)$. The percentage of protein decreased to $14.19,13.89$ and $13.74 \%$ in the salt concentrations 5, 10 and $15 \mathrm{~g} / \mathrm{l}$ respectively, in comparison with the control treatment (14.28\%).The percentage of fat amounted to 5.71, 5.68, and 5.66\% in the salt concentrations 5,10 and $15 \mathrm{~g} / \mathrm{l}$ respectively, in comparison with the control treatment $(5.73 \%)$. whereas the percentage of ash was increased to $3.01,5.40$ and $6.80 \%$ with the increase in salinity to 5,10 and $15 \mathrm{~g} / \mathrm{l}$ respectively, compared with the control treatment (1.80\%).
\end{abstract}

Keywords: common carp, salinity, time appearance of feces, chemical analysis 


\section{Introduction}

Salinity is considered the second most dangerous environmental factor after temperature that affects survival, distribution and growth of aquatics in general and fish particularly in fresh water bodies because it has negative effects on the environmental system balance, biodiversity and water quality degradation (Moorman et al., 2015). Both water scarcity and salinity are major issues facing agricultural sector in general and fish farming in particular (Hamed, 2008). The internal Iraqi water faces a continuous rising in salinity levels for many reasons such as: lake of water releases for Tigris and Euphrates Rivers, the effect of salty houses water entering Iraq, the drying of large areas of the Marshlands, lack of rain and decrease of rivers. Changes in salinity could lead to fish exertion for its effect on physiological balance and fish biological processes (Kültz,2015), for fresh water fish as Cyprinus Carpio changes appeared in blood standards when it is farmed in high salinity levels (Hilali and Alkshali, 2016). De Azevedo et al, (2015) suggested that fresh water fish could be more likely to develop infectious diseases. Gills and the digestion system in fish are the most important organs that might be affected with the surrounding environment and might play a crucial role in osmotic organization (Baysoy et al., 2013).

Water facing a continuous changes in salinity concentrations should be used in fish farming because of decreasing fresh water resources and the availability of brackish water which has minor uses, so fish should be naturalized to increase its ability to handle salinity in that water. Most fish living in fresh water including Cyprinus Carpio cannot handle high salinity levels because has a small salinity endurance. Stenohaline fish suffers deeply when it moves to salinity water because of what called osmotic shock (Jackson, 1981). It was found that fish salinity endurance could be increased by gradual transfer to water with a salinity level (Bardach et al.,1972). Chemical analysis of body components is a reflective mirror to the kinds and components of fish provender and the environmental circumstances that fish face. It is known that any exertion factor leads to a decrease of fat and protein because they are used as storage to produce energy that is used to put back the body in an internal stability status when organism avoids eating food or gets sick with cachexia, (Garcia et al., 2012). Fresh water fish need to organize the osmotic in salinity environments, thereby fish face water loses because of osmosis prosperity and the entry of ions in what called negative gain of ions (Evans., 1993), To avoid fish getting exposure to drought they drink water constantly, most of these water that fish drink goes to intestines the thing that cause to reduce food components, the average of drinking water has an important effect on emptying the gastrointestinal canal as of water pushes the digested food to intestines then out of the body., Also, the increase of salinity levels in the gastrointestinal canal hurries food passing and increases the average of gastric discharge (Dutil et al.,1997). Cyprinos Carpio is number one in fish farming in Iraq, but there are some factors threatening its survival and development such as the increasing of salinity levels in southern parts and some central regions of Iraq., The current study aims to detect the impact of salinity increasing in the osmotic organization for Cyprinus Carpio by studying some physiological indications to explore the negative effects for high levels of salinity, such as exertion and imbalance of osmotic and ionic organization processes, all of that reflects on body chemical analysis and average of waste appearance. 


\section{Material and Methods}

\section{Acclimating the Experiment Fish and Preparing Salinity analysis}

On 20/12/2015, 300 Cyprinus Carpio were brought with an average weight of 12-25 grams from one of fish farms in southern Baghdad. Glass tanks were used with dimensions of: $60 \times 40 \times 30 \mathrm{~cm}$, which equals almost 40 liters, and fully equipped with oxygen by an air pump. For around two weeks fish were given industrial fish food with a protein component of $31.9 \%$ by two meals daily and a percentage of $3 \%$ of body weight to Acclimating fish, the acclimation time period assess by the Behavioral changes in fish are often characterized by swimming velocity and the feeding rate (Pang et al, 2010).the provender, meanwhile during the experiment that took 90 days fish were given the same provender by 3 meals daily with a percentage of $4 \%$ of the body weight.

The salinity formations 5, 10 and $15 \mathrm{~g} / \mathrm{L}$ were made by dissolving a known weight of coarse salt from the local markets (Alsharqah Brand) in one liter of drinking water., Its salinity was taken in consideration and salinity of prepared formations was confirmed by measuring it by Salinometer Extech brand (USA), after acclimating fish on laboratory conditions. Salinity concentrations of $0.1 \mathrm{~g} / \mathrm{L}$ (tap water) fish were exposed to the abovementioned salinity formations gradually, same fish were moved to the higher concentrations after 4 days until reaching the last concentration, fish were exposed to the new concentration at the end of the fourth day of lower concentration, this duration was not counted to the experiment duration.

\section{Chemical Analysis}

Food provender and fish body components were analyzed after fish growth experiment and according to A.O.A.C., (1980) as follows

1) Humidity: humidity percentage was estimated by drying the samples on a temperature of $105 \mathrm{C}^{\circ}$ until the weight stabilized.

2) Protein: proteins were estimated using Microkjeldahl device, it digested a known weight of the sample by concentrated sulfuric acid and distillated the product by boric acid then the correction process is made with a hydrochloric acid of $\mathrm{N} 0.1$ to determine the nitrogen amount that multiplied in 6.25 to estimate the protein percentage in the sample.

3) Fat: fat were estimated using Soxhlet Apparatus device with Haksan as organic solvent by heating the sample for 8 hours daily and 16 hours for fish meat samples.

4) Ashes: ashes were estimated by burning the samples in muffle furnace on a temperature of $550 \mathrm{C}$ for four hours.

5) Carbohydrates: melted carbohydrates were estimated by nitrogen free extract (NFL) that mentioned by Wee and Shu (1989):

Melted carbohydrates $\%=100-($ protein $\%+$ fat $\%+$ ashes $\%)$

\section{Salinity Effect on Waste Time Appearance}

Eighty Cyprinus Carpio fish were distributed on eight glass tanks with ten fish on each tank, 
each concentration was made twice after Acclimating them on salinity concentrations: water 5,10 and $15 \mathrm{~g} / \mathrm{L}$. Fish were starved for 72 hours then were fed until satisfaction for two hours on a provender of protein component of $7.31 \%$, it has carmin color with a percentage of $1 \%$. Then the left food was taken out, the first waste appearance was recorded according to Talbot, (1985) method, which depend on tanks were examined regularly and the colour of the faeces was noted. The observation of a piece of bright-red faeces indicated that the carmine previously ingested was being excreted in significant amounts water temperature was between $22-23{ }^{\circ} \mathrm{C}$ and melted oxygen was between $7-6.7 .9 \mathrm{mg} / \mathrm{L}$.

\section{Statistical Analyse}

Data were analyzed using a completely random design, and data shown represent means \pm standard error. Significant differences between means were calculated using least significant differences (LSD). The data were analyzed by SPSS software Version 21.0 for Windows 7 (SPSS Inc., Chicago, IL, USA) (spss., 2008). Results were analyzed using a t-test for comparison between treatments. Statistical significance was set at $\mathbf{p}<0.05$

\section{Results}

\section{Chemical analysis of Body Components}

Table (1) pointed that humidity in Cyprinus Carpio was decreased with high salinity it reached $77.09,94.74,80.73 \%$ in salinity formations $5,10,15 \mathrm{gm} / \mathrm{L}$ gradually and in contrast to the sample (78.45\%), Protein percentage was decreased to $14.19 \%$ on $5 \%$ salinity then it drops to 13.89 and 13.74 on 10 and $15 \mathrm{~g} / \mathrm{L}$ salinity, in contrast to the sample (28.14\%) during the growth experiment that continued for 90 days.

Table (1) Chemical analysis for body components in Cyprinus Carpio before moving to various salinity concentrations on the basis of wet weight (values presenting average \pm Standard Error)

\begin{tabular}{|c|c|c|c|c|c|}
\hline \multicolumn{6}{|c|}{ Salinity concentration } \\
\hline Material & Tap water & 5 & 10 & & 15 \\
\hline Humidity & $\begin{array}{r}78.45 \\
\quad \pm 1.40 \\
a \\
\end{array}$ & $\begin{array}{ll}09.77 & 1.30 \pm \\
\text { a } & \end{array}$ & $\begin{array}{l}74.94 \\
\pm 1.17 \\
\text { b } \\
\end{array}$ & & $\begin{array}{lll}73.80 \pm & & 1.88 \\
& \text { b } & \end{array}$ \\
\hline Protein & $\begin{array}{c}14.28 \\
\pm 1.65 \\
\quad \mathrm{a}\end{array}$ & $\begin{array}{c}14.19 \\
\pm 1.80 \\
\quad \text { a }\end{array}$ & $\begin{array}{c}13.89 \\
\pm 1.12 \\
\text { b }\end{array}$ & & $\begin{array}{l}13.74 \\
\pm 1.57\end{array}$ \\
\hline Fat & $\pm 1.02^{5.73}$ & $\begin{array}{cc} & 5.71 \\
\pm \quad 1.10 \\
& a \\
\end{array}$ & $\begin{array}{l}5.68 \\
1.12\end{array}$ & $\begin{array}{l} \pm \\
\text { a }\end{array}$ & $\begin{array}{l}5.66 \\
\pm 0.54\end{array}$ \\
\hline Ashes & $\pm 0.08{ }^{1.80}$ & $\begin{array}{lll}3.01 & & 0.12 \\
& \pm & \\
& \text { b } & \\
& \end{array}$ & $\begin{array}{c}5.40 \\
0.16 \pm \\
\text { c }\end{array}$ & & $\begin{array}{c}6.80 \\
0.55 \pm \\
\text { d }\end{array}$ \\
\hline
\end{tabular}

- Various letters means there are significant differences on $(\mathrm{P}<0.05)$

The percentage of fat dropped down to $5.71,5.68$ and 5,66\% in salinity concentrations of 5, 10 and $15 \mathrm{~g} / \mathrm{l}$ gradually in contrast to the sample (5.73\%), while the ashes percentages raised 
to $3.01,5.40$ and 6,80 and salinity also has risen to 5,10 and $15 \mathrm{~g} / \mathrm{l}$ gradually and in contrast to sample (1.80). Statistical Analysis results showed that there were standard differences on salinity percentages and protein between the sample and salinity concentrations 10 and $15 \mathrm{~g} / \mathrm{L}$ meanwhile there were no standard differences $(\mathrm{P}<0.05)$ between the sample and concentrations $5 \mathrm{~g} / \mathrm{L}$, but there were standard differences between the sample and concentrations $5 \mathrm{~g} / \mathrm{L}$, and concentrations 10 and $15 \mathrm{~g} / \mathrm{L}$., There were no standard differences on fat percentage between the sample and all salinity concentrations meanwhile there were standard differences $(\mathrm{P}<0.05)$ in the ashes percentage between sample and all concentrations.

\section{Time Appearance of feces}

From Figure (1) it is noticed that the time appearance of feces was decreased when the salinity is high in Cyprinus Carpio., the time for food passing the gastronominal canal was less in high salinity water., The first appearance of feces in Cyprinus Carpio after 4.16 hours from eating food on salinity $15 \mathrm{~g} / \mathrm{L}$, but the time starts after 5.22 from having food on salinity concentration of $10 \mathrm{~g} / \mathrm{L}$ and after 6.11 hours in salinity concentration of $5 \mathrm{~g} / \mathrm{L}$ in comparison to the treatment sample (6.17 hours). Statistical analysis results showed that there are standard $(\mathrm{P} \leq 0.05)$ differences between the sample and salinity concentration of 10 and $15 \mathrm{~g} / \mathrm{L}$, while there were no standard differences between the sample and salinity of $5 \mathrm{~g} / \mathrm{L}$, also differences were standard $(\mathrm{P} \leq 0.05)$ between all salinity concentrations.

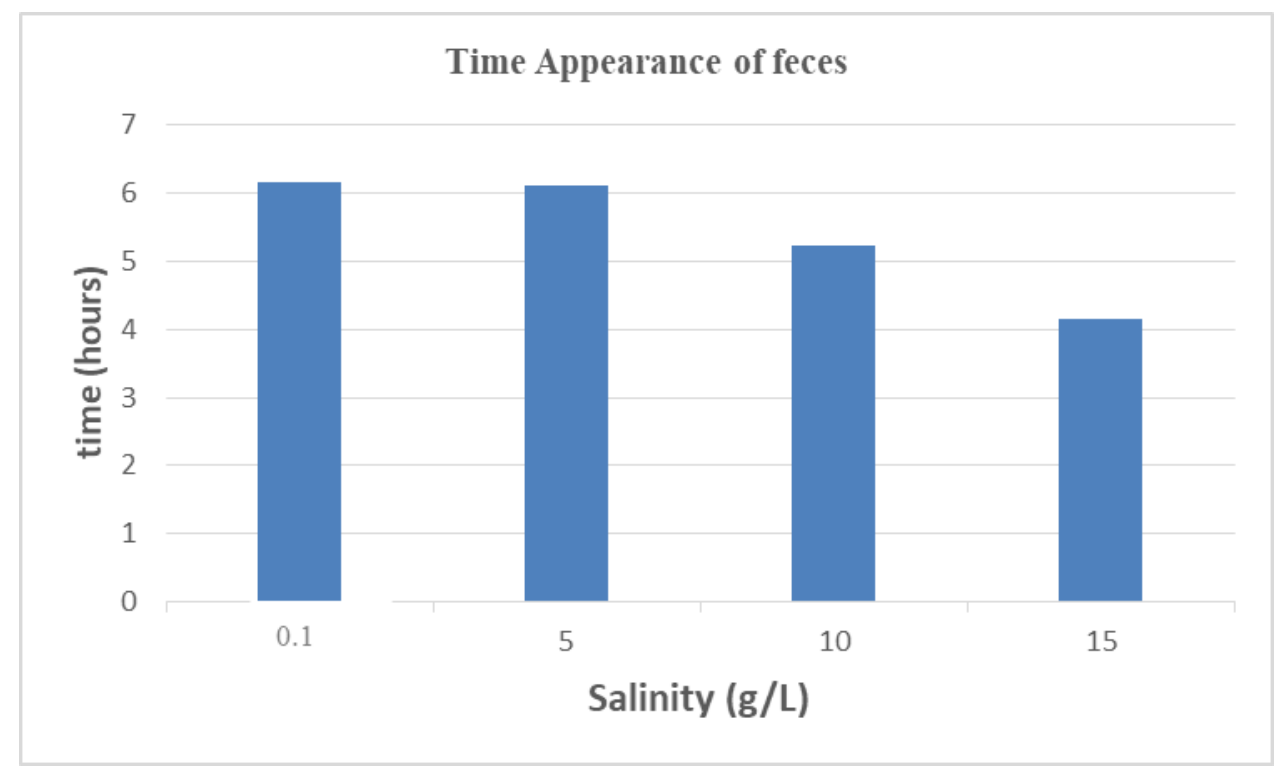

Figure 1. The time appearance of feces for Cyprinus Carpio in various Salinities

\section{Discussion}

\section{Chemical analysis:}

Differences in osmotic pressure can lead to lack of humidity the thing that pushes the water outside the body, fat is considered the main and the first energy resource for fish it is noted that it was decreasing, but as for increasing ashes levels it is a result of salt concentrations coming together, it might be that the provender which is an industrial one is consisted of some metallic elements or that fish are inside a salty environment that could increase the 
focus of ashes in the body.

As the current study results show that humidity is decreased in fish bodies when salinity concentrations were high, which is the result of osmotic effect that fish faced on high salinity level. Cyprinus Carpio cannot handle salty concentrations that is the reason behind the confusion that fish faced in organizing their body water as a result of increasing ionic load and losing water by osmotic effects outside the body the thing that could affect humidity inside body tissues (Prodocimo, et al, 2008). As for other body components (ashes, fat and protein) study results showed that the percentage of fat is decreased even though it was used as an energy resource all of that could be as an effect of provender food value because part of its components metabolized and other part settle in body tissues. (Csengeri et al, 1978), as for protein percentage it was recorded a decrease in the structure of fish bodies when the salinity concentrations used in this experiment were high.

As discussions were risen regarding salinity's effects on fish body formations, their results were divided into two groups: the first result group showed that there is no effect of salinity on body components such as humidity, protein, fat and ashes. However, other result group showed that there is indirect effect of salinity on the long-time term regarding the chemical formations of fish components, some referred the changes on chemical components of fish that faced high salinity environment to the component of industrial provender, while carp fish settle fat when being fed on provender of high carbohydrates and fat percentages (Hepher, 1988). (Ben-shan and shi-yen,(1999) pointed out that "in general" the chemical formation of fish bodies is affected by the components of previously given provender.

Fish got exposed to a high osmotic environment the thing that caused to lose their body water and to increase their body salinity, on behalf of other components. On the contrary, exposing fish to low osmotic environment causes to keep water body and to maintain its internal components (Smith, 1982). As for fat percentages: they play a crucial role because they are components to cells covers besides they are considered a source of energy; fat is used to prepare energy through the osmotic organization process (Tocher, 1993), fish bodies will use fat in providing energy by the liver to the entire body when facing any exhausting factor, fish are better than mammals in taking advantage of body fat when facing exhausting factors Figueiredo-(Garutti, et al, 2002). To discuss the reason of increased protein Philips (1969)) suggested that $70 \%$ of the calories in Oncorhynchus mykiss Trout are gotten from the protein inside the provender, when facing any exhausting factor, the biggest percentage of protein is transferred to energy to take benefit of it in completing osmotic organization correctly (McLean et al , 1999).

The availability of an amount of amino acid is crucial to complete the osmotic organization process correctly (Tseng and Hwang, 2008), the importance of proteins is not in being oxidizing factors that provide ATP energy only but also it plays a crucial role in organizing the ionic process by moving ions, too. Woo and Chung(1995) indicated that the body component from protein and fat in Pomacanthus Imperator were risen on salinity of 15 and $22 \mathrm{~g} / \mathrm{L}$ however, it was decreased on salinities 7,10. Meanwhile, (Abdel-Rahman, 1996) mentioned that salinity does not cause changes in body components of protein and fat in Red 
Hybrid Tilapia Fish.

Ahmed et al, (2005) mentioned that it was found that the chemical formations of body components for Heckel after spent 14 days in salinities of 1.5, 7 and $15 \mathrm{~g} / \mathrm{L}$ showed a decreased in protein and fat percentages and an increased in ashes percentage in salinity of 15 $\mathrm{g} / \mathrm{L}$. While (Eroldogan et al (2005) found that the ashes percentages in muscles, the component of dry materials, and salt percentage got increased, but no changes were found on the percentages of protein and fat for fish that depends mainly on provender with different salt percentages $(1,3,5$ and $9 \%)$.

Sultan, (2007) pointed in her study of Acanthopagrus Latus that there were a decrease of protein, fat and humidity percentages when fish are transferred to salinity concentrations of 23 and $30 \mathrm{~g} / \mathrm{L}$ in comparison to other concentrations as drinking water 3,7 and $15 \mathrm{~g} / \mathrm{l}$ and there was an increase of ashes percentages in the same experiment.

Al-Khshali, (2011) mentioned that humidity of Cyprinus Carpio was decreased with high salinity that reached $74.84,71.92$ and $70.72 \%$ in salinity concentrations of 4,8 and $12 \mathrm{~g} / \mathrm{L}$ gradually in comparison to the sample $(77.13 \%)$. Protein percentage was increased to $60.17 \%$ on salinity concentration $4 \mathrm{~g} / \mathrm{L}$ then it dropped to 57.18 and $55.28 \%$ on both salinity concentrations 8 and $12 \mathrm{~g} / \mathrm{L}$ gradually and in comparison, with the sample (58.55\%) during growth experiment that continued for 70 days.

As for fat percentage it was decreased to $25.78,25.64$ and $24.32 \%$ in salinity constructions 4, 8 and $12 \mathrm{~g} / \mathrm{L}$ gradually in comparison to the sample (27.80), while the ashes percentage increased to $11.04,13.14$ and $15.07 \%$, the salinity levels were increased to 4,8 and $12 \mathrm{~g} / \mathrm{L}$ gradually in comparison to the sample $(74.63 \%)$.

On salinity of $4 \mathrm{~g} / \mathrm{L}$ the protein percentage increased to $56.64 \%$ then it dropped to 52.14 and $50.23 \%$ on salinities 8 and $12 \mathrm{~g} / \mathrm{L}$ gradually and in comparison to the sample (54.82), as for fat percentage it increased on salinity of $4 \mathrm{~g} / \mathrm{L}$ to reach $26.80 \%$ but then it dropped to 24.73 and $23.25 \%$ on salinity concentration of 8 and $12 \mathrm{~g} / \mathrm{L}$ gradually and in comparison to the sample (26.68), while the ashes percentage increased to $11.85,12.70$ and $14.14 \%$ with an increased of salinity to 4,8 and $12 \mathrm{~g} / \mathrm{L}$ gradually and in comparison to the sample (11.24).

\section{Time of Appearance of feces}

When fresh water fish face an environment with high salinity levels. it drinks water that contains ions, The concentrations of those ions inside the fish bodies might be little so fish increase ions concentration inside its bodies to reach a balance status with external environment.

The digest process for food depends on many factors like food amount. Its quality, the sensitivity for food to enzymes activity, its secretions, and the time in which the food is exposed to digest enzymes. Many studies agreed that there is a negative relationship between high salinity and the time of waste appearance for fish: the result was explained on a basis that high salinity could increase the speed of food passing in the gastrointestinal canal the thing that cannot allow the gastrointestinal canal the suitable time to make digestion and 
absorption. Therefore, the enzymes were not given a chance to practice its fully activities, then decreasing the quality of metabolism (Mylonas, et al, 2009 ).

Salinity also affects the speed of food passing (Nordruma et al,2000) Also the high salinity increase the enzymes such as cortisol, growth hormone and prolactin hormone, the thing that affects the speed of food passing by affecting the brain and changing the entire animal behavior (Rubio et al, 2005). Current studies agreed with many other studies. Al-Khshali (2011) reported the time of waste appearance was decreased with high salinity for Cyprinus Carpio after 4.25 hours of having food on salinity of $12 \% \mathrm{~g} / \mathrm{L}$. after 5.35 hours of having food on salinity of $8 \mathrm{~g} / \mathrm{L}$ and after 6.20 in salinity of $4 \mathrm{~g} / \mathrm{L}$ in comparison with salinity of 0.1 $\mathrm{g} / \mathrm{L}$ (6.25 hours). It was noticed that there is an increase on the average of food moving in the intestines in the Golden Beaches, accompanied by a decline in growth averages (Yasir, 1996). Vinagre, et al, (2007) showed that an increase in the average of gastric discharge when the Solea Senegalensis faced salt water environment in comparison to the low salinity environment by $35 \%$. The experiment lasted 14 hours. (Al-Khshali, 2011) showed a decrease in the time of the appearance of the waste in the golden fish with an increase in its salinity. The rate of gastric discharge at the salt concentration was $12 \mathrm{~g} / \mathrm{L}$ faster than the salt concentration of $8 \mathrm{~g} / \mathrm{L}$. This was attributed to increase gastric passage.

\section{Conclusion}

The present study was conducted to effect of The gradual increase in salinity to 5, 10 and 15 $\mathrm{g} / \mathrm{L}$ on the Chemical analysis and Time Appearance of feces for Cyprinus Carpio that the appearance time of feces was decreased with the rise of salt concentrations of common carp and that confirms that salinity affects the digestive system of common carp fish on other hand it was found that the moisture dropped with the rise of salinity as and the percentage of protein decreased when rise the salinity concertation and as for the percentage of fat, was decreased the rise of salinity whereas the percentage of ash was increased and that confirms that salinity affects the chemical component.

\section{Acknowledgements}

This study has been supported by University of Baghdad. I appreciate the invaluable technical support of the Ministry of SCIENCE AND TECHNOLOGY in Iraq.

\section{References}

A.O. A. C. (1980). Official Methods of Analysis. Association of official Analytical chemists, Washington, DC, 1018.

Abdel-Rahman, S. H. (1996). Dietary protein requirement of juvenile red tilapia hybrid at different water salinities. J.Egypt.Ger.Soc.Zool., 20B, 103-117.

Ahmed, S. M., Dibikel, A. Y., Sultan, F. A. H. (2005). Effect of saline localization on the rate of intake of food, digestibility and the rate of discharge of waste in the fishes of the coarse fish Liza abu. Journal of Iraqi culture. 101, 2-109. 
Al Hilali, H. A., \& Al-Khshali, M. S. (2016). Effect of Water Salinity on Some Blood Parameters of Common Carp (Cyprinus carpio). International Journal of Applied Agricultural Sciences, 2(1), 2016, 17-20. https://doi.org/10.11648/j.ijaas.20160201.13

Al-Khshali, M. S. (2011). Effect of Different Salt Concentrations on Some Physiological and Nutritional Aspects of Grass Carp Ctenopharyngodon idella and Gold fish Carassius auratus, University of Baghdad, Department animal production, College of Agriculture, Ph.D Dissertation in Arabic p 120.

Bardach, J. E., Ryther, J. H., \& Mclarney, W. O. (1972). Aqua.: The Farming and husbandry of fresh water and Marine organisms. New York NY: Willey. (interscience) https://www.wiley.com/enus/Aquaculture $\% 3 \mathrm{~A}+$ The+Farming+and+Husbandry+of+Freshwat er+and+Marine+Organisms-p-9780471048268

Baysoy, E., Atli, G., \& Canli, M. (2013). The Effects of Salinity and Salinity+Metal (Chromium and Lead) Exposure on ATPase Activity in the Gill and Intestine of Tilapia Oreochromis niloticus. Arch Environ Contam Toxicol, 64(2), 291-300. https://doi.org/10.1007/s00244-012-9825-9

Ben-shan, C., \& Shi-yen, S. (1999). Both 0-3 and 0-6 Fatty acids are required for maximal growth of Juvenile Hybrid Tilapia North Amer. J. Aqua., 61, 13-20. Aquacult Bevalander, G. (1935). Acomparative study of the branchial epithelium in fishes, with special reference to extrarenal excretion. J. Morphol., 57, 335-351.

https://doi.org/10.1016/j.aquaculture.2013.09.003

Csengeri, I., Fakas, T., Majoros, T., Olah, T., \& szalay, M. (1978). Effect of feeds on the fatty acids composition of Cyprinus carpio L. Aquacult. Hung., 1, 24-34.

http://agris.fao.org/agris-search/search.do?recordID=HU8200820

De Azevedo, R. V., de Oliveira, K. F., Flores-Lopes, F., Teixeira-Lanna, E. A., Takishita, S. S., \& Tavares-Braga, L. G. (2015). Responses of Nile tilapia to different levels of water salinity. Lat. Am. J. Aquat. Res., 43(5), 828-835.

http://www.lajar.cl/pdf/imar/v43n5/Articulo_43_5_3.pdf

Dutil, J. D., Lambert, Y., \& Boucher, E. (1997). Does higher growth rate in Atlantic cod Gadus morhua. At low salinity result from lower standard metabolic rate or increased protein digestibility. Can J. Fish. Aquacult. Sci., 54, 99-103. https://doi.org/10.1139/f96-148

Eroldogan, O. T., Kumlu, M., Kir, M., \& Kiris, G. A. (2005). Enhancement of growth and feed utilization of the European seabass ( Dicentrarchus labrax) fed supplementary dietary salt in fresh water. Aquacult. Res., 36, 361-372.

https://doi.org/10.1111/j.1365-2109.2004.01211.x

Evans, D. H. (1993). Osmotic and ionic regulation. In D. H. Evans, The physiology (pp. 315-341). New York: CRC press.

Figueiredo-Garutti, M. L., Navarro, I., Capilla, E., Souza, R. H., Moraes, G., Gutiérrez, J., \& Vicentini-Paulino, M. L. (2002). Metabolic changes in Brycon cephalus (Teleostei Characidae) during post-feeding and fasting. Comp. Biochem. Physiol. A 132, 467-476. https://doi.org/10.1016/S1095-6433(02)00094-6 
Garcia, S. M., Kolding, K., Rice, M. J., Rochet, M. J., Zhou, S., Arimoto, T., \& Smith, A. D. (2012). Reconsidering the Consequences of Selective Fisheries. Science, 335(6072), 1045-1047. https://doi.org/10.1126/science.1214594

Hamed, Y. (2008). Soil structure and salinity effects of fish farming as compared to traditional farming in northeastern Egypt. Land Use Policy, 25(3), 301-308. https://doi.org/10.1016/j.landusepol.2007.08.006

Hepher, B. (1988). Nutrition of pond feshes. UK: Cambridge. University press,pp388

Jackson, A. G. (1981). Salinity tolerance and osmotic behavior of European carp (Cyprinus carpio L.) from the river Murray. Australia Trans. R.Soc.Aus., 103(7), 185-189. http://agris.fao.org/agris-search/search.do?recordID=AU8000116

Kültz, D. (2015). Physiological mechanisms used by fish to cope with salinity stress. Journal of Experimental Biology, 218, 1907-1914. https://doi.org/10.1242/jeb.118695

McLean, E., Rønsholdt, B., Najamuddin, \& Sten, C. (1999). Gastrointestinal delivery of peptide and protein drugs to aquacultured teleosts. Aquacult., 177, 231-247. https://doi.org/10.1016/S0044-8486(99)00087-3

Moorman, P., Lerner, D., Gordon Grau, L., \& Seale, A. (2015). The effects of acute salinity challenges on osmoregulation in Mozambique tilapia reared in a tidally changing salinity. Journal of Experimental Biology, 218, 731-739. https://doi.org/10.1242/jeb.112664

Mylonas, C. C., Pavlidis, M., Papandroulakis, N., Zaiss, M. M., Tsafarakis, D., Papadakis, I. E., \& Varsamos, S. (2009). Growth performance and osmoregulation in the shi drum( Umbrina cirrosa) adapted to different environment salinities. Aquacult, 287, 203-210. https://doi.org/10.1016/j.aquaculture.2008.10.024

Nordruma, S., Bakke-McKellep, A. M., Krogdahl, A., \& Buddingtonc, R. K. (2000). Effects of soybean meal and salinity on intestinal transport of nutrients in Atlantic salmon (Salmo salar L.) and rainbow trout (Oncorhynchusmykiss). Comparative Biochemistry and Physiology Part B: Biochemistry and Molecular Biology, 317-335.

https://doi.org/10.1016/S0305-0491(99)00190-X

Pang, X., Cao, Z. D., Peng, J. L., Fu, S. J. (2010). The effects of feeding on the swimming performance and metabolic response of juvenile southern catfish, Silurus meridionalis, acclimated at different temperatures. Comparative Biochemistry and Physiology Part A: Molecular \& Integrative Physiology, 155(2), 253-258.

https://doi.org/10.1016/j.cbpa.2009.11.005

Philips, A. M. (1969). Nutrition, digestion and energy utilisation. Fish Physiol. 1, 391-432. https://doi.org/10.1016/S1546-5098(08)60088-6

Prodocimo, V., Carine, F. S., Pessini, C., Fernandes, L. C., \& Freire, C. A. (2008). Metabolic substrates are not mobilized from the osmoregulatory organs (gill and kidney) of the estuarine Pufferfish Sphoeroides greeleyi and S.testudineus upon short-term salinity reduction, Neotropical. Ichthology, 6(4), 613-620.

https://doi.org/10.1590/S1679-62252008000400009 
Rubio, V. C., Sánchez-Vázquez, F. J., \& Madrid, J. A. (2005). Effects of salinity on food intake and macronutrient selection in European sea bass. Physiology \& Behavior, 85(3), 333-339. https://doi.org/10.1016/j.physbeh.2005.04.022

Smith, L. S. (1982). Introduction to fish physiology. Hong Kong: T.H.F.Pub.

SPSS, (2008). Statistical Package for Social Science. Release Version 17.0.1. SPSS Inc., Chicago.

Sultan, F. A. (2007). Effect of Salinity Acclimation on some Physiological and Nutritional aspects in Acanthopagrus latus (Houttyn, 1782) Juveniles. University of Basrah, ph.D. Dissertation. in arabic, P162.

https://www.researchgate.net/publication/282679753_Effect_of_Salinity_Acclimation_on_Gr owth_in_Acanthopagrus_latus_Houttyn_1782

Talbot, C. (1985). Laboratory Methods in Fish Feeding and Nutritional Studies. In P. Tytler, \& P. Calow, Fish Energetics (pp. 125-154). Netherlands: Springer. https://doi.org/10.1007/978-94-011-7918-8_5

Tocher, D. R. (1993). Elongation predominates over desaturation in the metabolism of 18:3n-3 and 20:5n-3 in turbot (Scophthalmus maximus) brain astroglial cells in primary culture. Lipids 28, 267-272. https://doi.org/10.1007/BF02536309

Tseng, Y. C., \& Hwang, P. P. (2008). Some insights into energy metabolism for osmoregulation in fish. Comp. Biochem. Physiol. C-Toxicol. Pharmacol., 148(4), 419-429. https://doi.org/10.1016/j.cbpc.2008.04.009

Vinagre, C., Maia, A., \& Cabral, H. (2007). Effect of temperature and salinity on the gastric evacuation of juvenile sole Solea solea and Solea senegalensis. Journal of Applied Ichthyology, 23, 240-245. https://doi.org/10.1111/j.1439-0426.2007.00852.x

Wee, K. L., \& Shu, S. W. (1989). The nutritive value of boiled full-fat soya bean meal in Pelleted feed for nile tilapia, Aquacult, 81, 303-314.

https://doi.org/10.1016/0044-8486(89)90155-5

Woo, N. Y., \& Chung, K. (1995). Tolerance of Pomacanthus imperator to hypo-osmotic salinities: changes in body composition and hepatic enzyme activities. J. Fish Biol., 47, 70-81. https://doi.org/10.1111/j.1095-8649.1995.tb01874.x

Yasir, A. K. T. (1996). The nutritional and phytochemical effects of salinity in the Golden Bay fish Liza carinata. PhD thesis, Faculty of Agriculture, University of Basram, 72.

\section{Copyrights}

Copyright for this article is retained by the author(s), with first publication rights granted to the journal.

This is an open-access article distributed under the terms and conditions of the Creative Commons Attribution license (http://creativecommons.org/licenses/by/4.0/) 